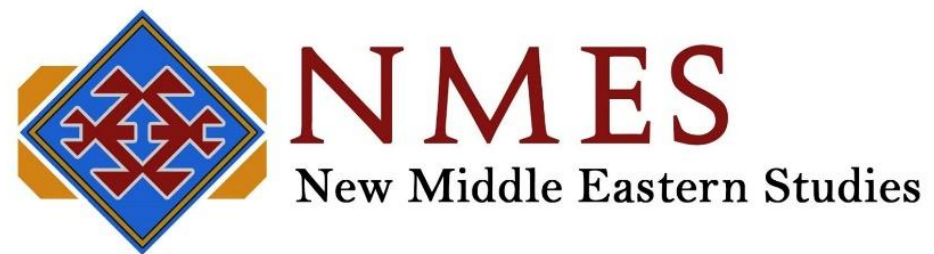

ISSN: 2051-0861

Publication details, including guidelines for submissions:

https://journals.le.ac.uk/ojs1/index.php/nmes

\title{
A Re-evaluation of the Revisionist - Status Quo Dichotomy in Interwar Turkish Foreign Policy, 1936-1939
}

Author(s): Mustafa Çoban

To cite this article: Çoban, Mustafa (2018) "A Re-evaluation of the Revisionist - Status Quo Dichotomy in Interwar Turkish Foreign Policy, 1936-1939”, New Middle Eastern Studies 8 (1), pp. 1-22.

Online Publication Date: 5 June 2018

\section{Disclaimer and Copyright}

The NMES editors make every effort to ensure the accuracy of all the information contained in the journal. However, the Editors and the University of Leicester make no representations or warranties whatsoever as to the accuracy, completeness or suitability for any purpose of the content and disclaim all such representations and warranties whether express or implied to the maximum extent permitted by law. Any views expressed in this publication are the views of the authors and not the views of the Editors or the University of Leicester.

Copyright New Middle Eastern Studies, 2018 All rights reserved. No part of this publication may be reproduced, stored, transmitted or disseminated, in any form, or by any means, without prior written permission from New Middle Eastern Studies, to whom all requests to reproduce copyright material should be directed, in writing.

\section{Terms and Conditions}

This article may be used for research, teaching and private study purposes. Any substantial or systematic reproduction, re-distribution, re-selling, loan or sub-licensing, systematic supply or distribution in any form to anyone is expressly forbidden.

The publisher does not give any warranty express or implied or make any representation that the contents will be complete or accurate or up to date. The accuracy of any instructions, formulae and drug doses should be independently verified with primary sources. The publisher shall not be liable for any loss, actions, claims, proceedings, demand or costs or damages whatsoever or howsoever caused arising directly or indirectly in connection with or arising out of the use of this material. 


\title{
A Re-evaluation of the Revisionist - Status Quo Dichotomy in Interwar Turkish Foreign Policy, 1936-1939
}

Mustafa Çoban*

\begin{abstract}
Turkish history during the interwar period (1918-1939) has been described in terms which place it on a dichotomy best used to analyse the actions of the eventual belligerents in World War II. This dichotomy describes the eventual defeated Axis countries as revisionist and the victorious Allies as status quo nations in the interwar period. The contention is that this distinction, taking as its basis the actions of belligerents, is unhelpful in analysing the foreign policy of a non-belligerent state in WWII.

Three case studies are examined through the secondary literature as well as archival sources to show that notions of Turkey as either status quo or revisionist are not entirely accurate. This is because Turkish foreign policy can be classified as either or both, thus diminishing the terms' explanatory utility. Three case studies are; the Montreux Straits Convention (1936), the Saadabad Pact (1937) and the Sanjak dispute of Alexandretta (1936-39). A reading of history which assumes macro level (1914-1945) superiority based on Great Power interests and actions undermines the complexity of Turkish foreign policy in the 1930s. By extension, the practice of subsuming the actions of smaller states under terminology which was intended for Great Powers is challenged.
\end{abstract}

Keywords: Turkey, Status quo, Revisionist, Montreux, Alexandretta, Saadabad

\section{Introduction}

In broad terms, Turkey's foreign policy between the World Wars of the 20th Century has been well studied since the 1970s. The secondary literature produced in English and Turkish shows a heavy reliance on the British archives, added to by the memoirs of diplomats, politicians and contemporary press material. The conclusions have in some cases become directed towards a retrospective reading of Turkish interwar history, by placing it in either the status quo or revisionist camp. The following study aims to critique this restrictive use of language in the historiography.

In the context of pre-1939 diplomacy, a status quo state was one which attempted to maintain the post-World War I international settlements concluded in the palaces around Paris in 1919. Revisionists states on the other hand attempted to revise these settlements. However further connotations complicate the picture. Since the eventual belligerents of WWII were broadly divided along this polarity, the implication is that a status quo state is one that seeks to maintain peace on the side of Britain and France. Consequently, a revisionist label implies a

*Mustafa Çoban, School of History and Cultures, University of Birmingham, Edgbaston, Birmingham, B15 2TT, UK. Email: mxc481@bham.ac.uk. 
closer alignment with Nazi Germany and Fascist Italy. This dichotomous use of terminology in foreign policy analysis in the immediate pre-World War II era is problematic when ascribed to Turkey because: a) Turkish foreign policy does not fit into either classification, or rather it can fit into both, which brings the utility of the terminology into question. b) The eventual belligerents of WWII were broadly divided along a status quo - revisionist polarity. c) Turkey, in difference to all other states in the narrative, remained neutral in WWII. It is therefore problematic to ascribe the terminology retrospectively to a non-belligerent of the war. Although issues remain, the terms are more easily applicable to the Great Powers. This produces a tendency to view the interests, objectives, aims, outcomes and complexities of nations without the label of Great Power to become subsumed under major power narratives of history. However, it is not contested that the terms have explanatory value when placed in their appropriate historical context.

After further setting out the claim and context, three cases of Turkish foreign policy action will be examined. These are, the Montreux Straits Convention (1936), the Saadabad Pact (1937) and the Sanjak dispute of Alexandretta (1936-39). These have been chosen because of their largely concrete outcomes, their scope for measuring Turkish foreign policy action on its European and Middle Eastern borders and potential for the misapplication of the terms revisionist and status quo. As an exercise in qualitative comparison, British archive material is used in conjunction with the secondary literature under consideration. This secondary literature, though not exhaustive, does constitute a representative sample of Turkish foreign policy studies in general and to the 1930s and 1940s in particular. The overall intention here is neither to criticise their data nor their valuable contribution to European, Middle Eastern and Turkish history on the whole. It is rather to suggest that nuanced understandings of history which reject polarisation may be more useful in developing the understanding of interwar Turkish foreign policy.

The rather mundane point of foreign policy expedience and calculated self-interest is followed throughout the study. This is done in conjunction with the understanding that placing Turkey on the side of the winners of WWII - the good, the just, the status quo - or the losers the bad, the malicious, the revisionist - is unnecessary. Further, there is no claim to replace the existing dichotomous framework of analysis. It is hoped that an empirical critique will allow for further discussion and analysis of the issues pertaining to the foreign policy study of subGreat Power states in the pre-WWII period. As such, a null hypothesis is proposed on Turkey's place on a revisionist - status quo dichotomy.

Such a claim may seem superfluous, after all the diplomatic dynamics leading to WWII are well studied. On the other hand, one may assert that the distinction presented between status quo and revisionist states is one between belligerents. It is because Turkey did not fire a shot in anger that it should be disentangled from this oppositional understanding of pre-war diplomacy. It is instead more important to understand why and how Turkey remained neutral and to see how it deployed diplomatic initiative to achieve policy goals in a contemporary environment increasingly polarised between the revisionist and status quo powers. 


\section{The Claim and Context}

It could be argued that Turkey was born as a revisionist state. The nationalist leadership in Ankara having rejected the Treaty of Sèvres, signed by the Ottoman government in August 1920, to later abolish the Ottoman Empire and negotiate a treaty at Lausanne in 1923 (Sharp 1991: 39). However, there are then problems of periodization and whether Lausanne was a revision since it was signed by a new entity. Further, Lausanne can be seen as the most successful of the post-1918 settlements, chiefly because it was negotiated rather than imposed and set around demands that were realistic, limited and attainable (Sharp 1991: 175). Nor were Turkish decision makers bound so closely to the treaty that they could not take advantage of shifting circumstances in the 1930s. Since Lausanne came about through multi-lateral compromise and negotiation Turkey can also be described as a born status quo state.

The issue of dichotomisation begins with the belligerent sides at the conclusion of WWI and the post-War settlements. Of the great powers Britain and France were on the winning side, largely dictating the peace at the expense of Germany and Austria-Hungary. In this simple illustration lies the first major problem. It can be reasonably assumed that the winning Entente would have liked to preserve the settlements they drew up, while the injustice felt by the losing Central powers would lead them to seek revision. Hence the superficially clear-cut demarcation of the status quo camp on one side and the revisionists on the other. The simplicity of the line and the analytical opposition of the belligerents takes us only so far in understanding the causes and consequences of two world wars. Indeed, by grouping countries on the basis of the winners and losers in both wars, smaller but no less significant countries in world history are subsumed into these camps retrospectively.

Save for the case of Turkey, there is little argument on which side of this divide most countries belonged to. According to William Hale (2000: 61), Greece, Serbia and Romania, which were on the winning side in WWI, took a pro-status quo, or anti-revisionist position, with Bulgaria and Hungary in the revisionist group. The division thus far adheres to the sides outlined above. The line becomes blurred with the addition of Italy into the equation. Although a winner in 1918 Italy was at odds with the new Yugoslavia and therefore a revisionist (Hale 2000: 61). The initial impulse of equating the winners of WWI with the status quo and losers with revisionists is not entirely clear cut. Hale (2000: 60) discusses the withdrawal of Germany, Japan and Italy from the League of Nations as a strengthening of the revisionist camp. Importantly, while he shows the contemporary demarcation, Hale's characterisation is contextually grounded in the historical processes which show how the history can and has been written without a terminological bias. Hale's analysis continues in the traditional understandings of Turkish foreign policy in its attempts to exploit the prevailing balance of power and take advantage of Great Power rivalries (2000: 70). This approach may also support the neutral view of Turkey's place on a dichotomous reading.

The case of the USSR is also avoided in the literature. This is perhaps due to the special place afforded to it due to the Russian Revolution and the Cold War on either end of the chronology of the World Wars. To be sure, Soviet interests are discussed and analysed by all historians of inter-war Turkey. However, its place on the dichotomous understanding is conspicuous by its common absence. 
The nations placed on either side of the revisionist - status quo line so far have been those which took an active part in WWII. Turkey as a somewhat special case has attracted scholarly attention attempting to place it on this analytical line. Baskın Oran (2006), in his comprehensive edited work on Turkish foreign policy from 1919 to 1980, identifies two important developments leading to WWII. These are the world economic crisis following 1929 and the revisionist - status quo struggle, borne out of the harshness of the Paris treaties. These camps are seen as competing for the favour of geo-strategically important Turkey (Oran 2006: 242). The book is rich in detail and has many contributors, indicating a measure of consensus among Turkish historians. İlhan Uzgel and Ömer Kürkçüoğlu's chapter (2006: 258-77), on Anglo-Turkish relations, emphasises the aggressive and revisionist policies of Italy in the Eastern Mediterranean as a causal factor in Turkey's closer alignment with the status quo camp (2006: 271). Uzgel further asserts a German view of a possible place in the revisionist camp for Turkey following Turkey's revision of its southern border with Syria (2006: 302). Overall, in Oran's estimation Turkey is seen as a status quo nation because it did not present the League of Nations with the type of irredentism and expansionism shown by Germany and Italy. Any revision to Turkey's standing agreements were achieved by mutual agreements under international law and specifically without faits accompli (Oran 2006: 48). However, the implication of allying with Britain and France retrospectively is a convenient historiographical precedent for siding with the just. Nor is Turkey's comparative lack of military resources relativized against the coercive capabilities of Germany and Italy.

The aforementioned issue of the just finds expression with those who reject moralistic conclusions. Selim Deringil (1989: 185) defends Turkish foreign policy on the grounds that Turkey spared itself the destruction which affected so many other countries during the war, further placing Turkey in the status quo camp. However, the analysis lacks discussion of Turkey's expanding borders to include Alexandretta. Deringil's statement seems to be a challenge to that of Frank Weber, who declares: 'Turkish diplomacy during the war was a brilliant accomplishment except those of honesty and integrity' (1979: 219). Weber goes on to suggest that Turkish policy in Cyprus in the 1970s had causal antecedents in Ankara's dissatisfaction with diplomatic efforts surrounding WWII (1979: 219). Further he sees Turkish policy on Alexandretta as pre-existing revisionism (Weber 1979: 18). In his selective and uncritical reading of British archives, Weber also imagines Turkish designs on the Dodecanese islands, Bulgarian Thrace, Albania and Salonica (1979: 60). Although Weber does not use the terms revisionist or status quo, his indictment of Turkish foreign policy on these moral and imagined grounds leave little doubt as to his placement of Turkey on the malicious, and therefore revisionist, side of those nations involved in pre-war and war time diplomacy.

Ludmila Zhivkova (1976) tends to agree with the revisionist charges of Weber for different reasons. Brock Millman describes her criticism as stemming from a Marxist perspective (1995: 483). Though there is a case for this it might instead be described as regret for closer Turkish alignment to Britain at the expense of Turkish relations with the USSR. Emphasis is placed on Turkish remilitarisation of Thrace and its resultant threat to Balkan and more particularly Bulgarian security (Zhivkova 1976: 35), rather than the administration of the Straits itself. Charges of illicit Anglo-Turkish deals at the expense of the USSR and the Black Sea littoral states during the Montreux Conference (Zhivkova 1976: 40 \& 43) are seen as 
examples of the right-wing Turkish ruling class abandoning their previously anti-imperialist course (Zhivkova 1976: 118). Interesting though the effects of the early Turkish Republican class system's role in diplomatic history may be, Zhivkova's narrative and conclusions seem tainted by a Cold War context which sees the NATO member Turkey as a security threat to the Warsaw Pact's southern flank. Her sources may also be questioned for a conspicuous absence of Bulgarian documents. As the daughter of the Bulgarian head of state Todor Zhivkov, it is not unreasonable to suspect that she might have had more privileged access to Bulgarian archives compared to many others.

One further example may serve to clarify the contention, 'The basically revisionist character of German foreign policy did not comport with Turkey's devotion to the status quo. Ankara had as great a stake in preserving peace as any other status quo power...' (Güçlü 2000: 74). Read in isolation, this piece of analysis containing a summation of the incompatibility of German and Turkish foreign policy seems innocuous. Yet, tainted by the prevalence of the oppositional terminology further erroneous conclusions can be drawn. If it becomes accepted that Turkey was a revisionist power, by implication then Turkey should have had no qualms committing its diplomatic and military resources to any Axis effort and expect reciprocity. German and Italian objections and misgivings towards Turkish efforts to renegotiate the Straits at Montreux undermines this. Similarly, accepting unconditional Turkish adherence to a status quo position might assume full cooperation with Britain and France. As will be seen the situation was more nuanced than simple polarisation would suggest.

After this initial overview one may form the impression that the terms 'revisionist' and 'status quo' are themselves under scrutiny here, this is not the case. The terms do carry explanatory value when deployed in their historical context. Germany and Italy did pursue increasingly aggressive policies aimed at revising the post-Paris status quo in the 1930s while Britain and France generally attempted to counter this. However, labelling Turkey a revisionist ignores its efforts to maintain and, in some cases, strengthen the status quo. Similarly, a status quo label leaves out the fact of expanded Turkish borders in the 1930s through nationalist, ethnic and linguistic irredentism.

In commentary such as that of Dilek Barlas: 'Balkan cooperation took root initially as a reaction to the emergence of revisionist powers, in particular Italy' (2005: 444) - the use of the terms 'status quo' and 'revisionist' do not in themselves assert a place on a dichotomy but illustrate contemporary developments. On the other hand, when Millman (1995: 484) asserts that: 'To date, revisionists have largely gained the field... Their version has been preferred despite evidence which... supports the traditional view [status quo] of Turkish policy', the history is retrospectively couched in oppositional terms.

The matter is further complicated by the fact that those powers discussed as revisionists were eventually defeated by the status quo powers. While a good versus bad position is often an emotive issue with regards to WWII, placing the non-belligerent Turkey in this argument is unnecessary. It would be the prerogative of further country specialists and general historians to explore whether this rejection of opposites can be applied to other areas of diplomatic history. Indeed, the issue may reach beyond diplomatic history. Further research into domestic factors, economic and cultural production, industrialisation, state formation, ethnic politics and nationalism, to name a few, may yield data to further elucidate the processes of interwar history. 
In sum, the terms revisionist and status quo in the interwar period taking as they do their initial classification from the results of the 1914-18 war, are insufficient. If the winners of WWI were status quo in the inter-war period, then Italy and Japan as revisionist powers is problematic. If the losing states were revisionists, then Turkey should also be included with them, despite its considerable diplomatic efforts to preserve the status quo. The simple division ignores the considerable domestic changes that took place in the transition from Ottoman Empire to Republican Turkey, and by extension the domestic developments of all other states mentioned. Second, the terms are useful when viewed in their appropriate context; they clarify contemporary policy and diplomatic objectives. The central claim is that it is problematic to ascribe the terminology retrospectively to a non-belligerent state of WWII.

\section{The Montreux Straits Convention 1936}

After the Greco-Turkish War of 1919-1922 and the Treaty of Lausanne which followed it in July 1923, the territory of the new Turkish Republic was largely set. At Lausanne, Turkey had agreed to the internationalisation of the Straits and the demilitarisation of its Thracian border in exchange for international recognition of Ankara's sovereignty. What came next was an ideologically driven socio-political restructuring. Some of the highlights were the abolition of the Caliphate, replacement of the Arabic script with Latin, adoption of family names and women's suffrage. In short, Turkey was internally orientated towards nation building for much of the interwar period. With the 1930s came the global economic crisis and the increasingly aggressive claims of countries such as Italy and Germany. The rising revisionist environment coincided with increased Turkish activity in foreign affairs. Increased foreign policy action from the early 1930s lead to the Turkish proposal on revising a portion of Lausanne in what came to be known as the Montreux Straits Convention. It is important to note that this revision was limited to the Straits. Ankara did not seek to revise other clauses of Lausanne such as the status of its land borders, Aegean Islands or Cyprus. The Turkish aim was limited revision of an international treaty within the parameters of international law, essentially a legalistic course of seeking broader security in an increasingly hostile environment.

The Montreux Conference was not a spontaneous reaction to diminishing European security. Turkish accession to the League of Nations in 1932 served as a forum for the gradual clarification of Turkish views about the revision of the Straits settlement (Trask 1971: 228). It was not surprising therefore for the Lausanne signatories when Turkey informed them of its desire for treaty revision when the formal request was communicated on 10 April 1936 (VereHodge 1950: 123). The request was based on the principle of rebus sic stantibus, meaning that the international circumstances had changed to such an extent that the revision of the settlement had become essential (Özersay 2006: 371).

Certain conditions came to favour the request. In the preceding month Germany had remilitarised the Rhineland, Italy on the other hand had already begun its Abyssinian offensive in October 1935 (Vere-Hodge 1950: 123), going against the spirit of the Kellogg-Briand Pact of 1928. This Pact was an attempt to promote peace by outlawing war in the resolution of international disputes (Trask 1971: 219), a document with little more value than idealistic rhetoric. Both Germany and Italy had presented the international community with a fait 
accompli, taking calculated risks for their interests in the face of little more than condemnation. Here Weber's description of the Turkish Foreign Minister Tevfik Rüştü Aras as, a keen opportunist with an excellent sense of timing (1979: 5), seems to hold true. The Turkish delegate at the League of Nations did no more than join the general condemnation of Germany over the Rhineland, essentially toeing the line of the status quo camp (Soysal 1981: 124). It would not do to kick up a fuss when Ankara wished to revise the Straits settlement.

Turkey did not present a similar fait accompli to the League through a unilateral remilitarisation. The application of pacific means in the spirit of the Kellog-Briand Pact and the League Covenant raised Turkish prestige when contrasted to the actions of Germany and Italy (Trask 1971: 230). Prestige notwithstanding, Turkey's military capabilities were much lower than those of Germany and Italy. Provoking Soviet antagonism and British disapproval on an important sea route was beyond Turkish interests or capabilities.

Most Lausanne signatories had their reasons for accepting the Turkish request. Anthony Eden, then British Foreign Secretary, recalls that the Admiralty favoured a pro-Turkish solution, emphasising that gaining Turkish co-operation outweighed the disadvantages of Turkey refortifying the Straits (1962: 419). This co-operation was based on the British desire to use Turkey as a counterweight in three possible zones; against Italian expansion in the Mediterranean, increased German economic penetration in the Balkans and potential Soviet action in the Middle East (Barlas 1998: 165). Accordingly, in his memorandum to the British delegation at Montreux, Eden authorised them to agree to the abrogation of demilitarisation, stressing that: 'It is most important that this concession ... should be made as generously and completely as possible from the outset' (Eden 1962: 420).

The USSR concurred that Turkish fears of insecurity were well founded (Degras 1953: 189). Far from this friendly attitude, Soviet desideratum was based on misgivings concerning the previous settlement. They aimed at gaining unfettered naval access to the Mediterranean while pushing for a closure of the Straits to the warships of all non-Black Sea states (Bilge 1992: 115), thus seeking naval domination. Bulgaria saw an opportunity to revise the border demilitarisation clauses of its own Treaty of Neuilly (1919), while the primary French interest lay with strengthening the 1935 Franco-Soviet Pact (Özersay 2006: 372).

There was opposition too. Italy was concerned that the Conference was directed against its Mediterranean interests (Barlas 1998: 166). Mussolini would not have relished the prospect of encountering the Soviet Navy near the Dodecanese. Since Turkey was involved in the League sanctions against Italy, the latter refused to formally join the conference, sending only an observer (Weber 1979: 8). Germany did not make an immediate complaint, by initially supporting the initiative as a revisionist power, it hoped it would give Turkey greater independence from the USSR (Barlas 1998: 166). Nevertheless, the potential expansion of Soviet influence was not compatible with German interests. Britain was the party concerned on this point, since unlimited Soviet military access to the Mediterranean might drive Germany to cancel the 1935 agreement with Britain regarding naval rearmament (Özersay 2006: 373). Berlin's later unclear complaint to Turkey, ${ }^{1}$ can be viewed as an attempt to voice frustration at Turkey's rapprochement with Britain. It can be seen here that straightforward understandings of the motives of revisionist powers is limited compared to the competing interests of all nations. 
The conference opened on 22 June 1936 with the participation of Australia, Britain, Bulgaria, France, Greece, Japan, Romania, Turkey, the USSR and Yugoslavia (Hurewitz 1956: 197). ${ }^{2}$ The Turkish draft treaty was accepted as a basis for discussion. Under this, Turkey aimed at obtaining commercial control over the Straits by abolishing the Straits Commission and the right to refortify the Straits zone. The Soviet Foreign Minister Maxim Litvinov showed his acquiescence to the latter clause (Degras 1953: 194). In the statement putting forth the Soviet position, he stressed the need for increased security in the Black Sea by alluding to the limitations which should be placed on non-riparian naval access to the Black Sea (Degras 1953: 193). Coming the day after the conference opened, this was a thinly veiled statement indicating the Soviet desire to exclude all warships of non-Black Sea states.

Unsurprisingly, this turned out to be the primary obstacle to agreement between Britain and the USSR. A dispatch by Aras to the Foreign Ministry from Geneva may sum up the problem: 'Britain wants to cap naval power, therefore cannot come to a definitive stance on the Straits, and Litvinov is against limiting Russian Naval activity through the Straits' (Bilge 1992: 118). This put Turkey in an unpleasant situation. French support for the USSR turned out to be an important factor, by having a Western European power as well as the Black Sea states on its side Moscow succeeded in limiting non-Black Sea naval activity through the Straits (Özersay 2006: 374).

If London was forthcoming towards the Turkish desire for remilitarisation, it did not give up on the International Straits Commission immediately. This was of fundamental importance to Turkey since its continued existence would legally bind Ankara to an international body on its sovereign territory. To offset the British position, Turkey leaned towards the Soviet proposal limiting non-riparian warship access to the Black Sea to facilitate the abolition of the commission. However, suggesting that the British suspected the origins of Turkish policy to be in Moscow (Weber 1979: 7) would be implying Turkey's satellite status to the USSR. Britain, realising that no agreement could be made without a Soviet signature, dropped some of its requests (Barlas 1998: 169). The resulting convention was signed on 20 July 1936, coming into force on 9 November after a sufficient number of ratifications were deposited (Shotwell and Deák 1940: 126). The settlement was a success for Turkey but was also in the Soviets favour. Although the Soviet Navy was left as the master of the Black Sea (Shotwell and Deák 1940: 127), the USSR did not feel satisfied. Litvinov summarised the Soviet position at the closing session of the conference:

The conference has recognised, although inadequately, the special rights of the Black Sea countries in that Sea and in regard to the passage of the Straits, as well as the special geographic situation of the Black Sea, to which the general conception of the complete freedom of the seas cannot be applied in full (Degras 1953: 200).

Despite their misgivings, the USSR regarded Montreux as an improvement on Lausanne. The principle advantage was the tonnage restrictions placed on non-Black Sea warship passage through the Straits (Hurewitz 1956: 199). ${ }^{3}$ 
A noteworthy area of friction was the Soviet overtures towards Turkey running parallel with the conference. Realising a general agreement was to be forthcoming on remilitarisation, Litvinov sounded out Aras about the possibility of a bilateral alliance to protect the Straits (Bilge 1992: 120). Cautious of increasing the already substantial Soviet interests at the Straits, and mindful of avoiding becoming too close to any one power, the Turkish government rejected the offer, citing the refortification contracts as a financial issue that the Soviet Union could not fulfil at the time (Bilge 1992: 121). In a double stroke the Turkish government resolved the fortification problem by granting the concession to the British firm Vickers (Vere-Hodge 1950: 120). This allayed Soviet apprehension that the contract would be awarded to the German Krupp company, while it was also a gesture of friendship and increased economic ties with Britain.

Ankara, no longer as anxious about its security at the Straits, was able to seek closer relations with London. Though the Convention appeared to favour the USSR more than Britain, the former's remaining misgivings were not shared by the latter. Having opened the door to Soviet naval presence in the Mediterranean, Britain provided another power for Italy to contend with. London could now aim at closer relations with Ankara, knowing that Turkish security fears were prompted by Italian action in the Mediterranean. Additionally, through the control of the Suez Canal, Cyprus, Palestine, a high degree of influence in Iraq as well as RAF (Royal Air Force) bases there and a developing rapprochement with Turkey, British security interests in the Eastern Mediterranean appeared to be well served. Indeed, Britain would go on to advise Turkey to abstain from a Black Sea pact initiated by Moscow the following year, citing the potential anxiety it would generate in Germany and Italy. ${ }^{4}$ The increase in the number of states with a Mediterranean security interest was also useful for Turkey since it now held the keys to the Straits and wished to gain British security guarantees without appearing to court London exclusively.

In sum, a standing international agreement was revised in favour of but without wholly repudiating another, with the aim of protecting the larger status quo. In revising the status of the Straits, Turkey can be shown to have achieved a non-aggressive and legal revision. The fact that the treaty has survived until the present also affords it a not insignificant legitimacy compared to other short-lived revisionist treaties of the 1930s.

\section{The Saadabad Pact 1937}

The Saadabad Pact has yet to be studied in any great detail. One reason is that it was rendered largely irrelevant from an operational point of view with the outbreak of the war two years after signature. The sovereign interests of Iran and Iraq were subsumed under the global war strategy of Britain and the USSR. Afghanistan was fairly peripheral in the war and Turkey pursued neutrality. Second, the document which was signed contained little that was tangible. However, the fact that it was signed and the deliberations leading to it were of significance. It was the first instance of sovereign Middle Eastern nation states coming to an understanding of collective security, without overt Great Power initiative or pressure. More importantly for this study it provides a test case for whether Turkish foreign policy was qualitatively different in its dealings with the Middle East compared to Europe. As will be seen, this is complicated by 
the fact that although Saadabad contributed to the overall status quo in the Middle East, it also allowed space for Turkey to pursue revisionism in Syria. Thus, contributing further to the diminishing explanatory value of the dichotomous terms to Turkish foreign policy. The evidence suggests Turkish policy was active in bringing about signature. The benefit for Turkey was the maintenance of the status quo on its Eastern borders facilitated by encouraging better relations between Iran-Iraq and Afghanistan-Iran.

The Middle East at this time was somewhat secondary to Turkey's relations with Europe. For European powers however, Turkey's location on Arab, Iranian and Soviet borders was important. A solid Turkish friendship for Italy or Germany could, in theory, challenge the Franco-British dominance of the Eastern Mediterranean. On the other hand, if Turkey were allied to Western European powers, the consolidation of this area could deter would be aggressors. Turkey opted for the third option of neutrality. Ankara's engagement with the Middle East was directed towards obtaining a degree of peace on its Eastern borders in order to concentrate efforts further west.

The origins of the Pact had been initialled in Geneva in October 1935 between Turkey, Iran and Iraq, Afghanistan acceded in January 1936 after Muhammad Khan's visit to Ankara (Akdevelioğlu and Kürkçüoğlu 2006: 367; Watt 1988: 338). What is arguably more important is the process of the resolution of the Shatt al-Arab question between Iran and Iraq, this was a prerequisite for signing the four-power pact. In this context Turkish overtures towards closer diplomatic and economic relations with Iran and Iraq and Ankara's subsequent role in resolving Perso-Iraqi differences are important.

Turkish interest in the Middle East had an economic security dimension, primarily of diversification. Ankara wished to direct a portion of trade away from the Soviets. Proposals to build a rail link with Iraq for direct access to crude oil instead of relying on Soviet supplies via Romania were well received by London. ${ }^{5}$ The British Naval Attaché in Ankara submitted a report suggesting that Turkey could be supplied with oil through a rail link with Iraq in the event of the disruption of sea communications. ${ }^{6}$ So much so that on Aras' trip to Baghdad, as part of the Shatt and Saadabad negotiations, he was accompanied by the Turkish Minister of National Economy in order to raise the question of direct oil supplies. ${ }^{7}$ The problem of finance was the main obstacle, the Iraqi government agreed on the point of economic advantages then alluded to the unavailability of funds to pursue it. ${ }^{8}$ It is difficult to gauge how far the Iraqi government were reminded of Turkish designs on Mosul in the 1920s and whether Turkish action on Alexandretta prompted them towards caution on this point.

Similarly, efforts were made at economic cooperation with Iran. The difference here was Iran's geography and Reza Shah Pahlavi's policy towards increasing independence from the USSR and Britain (Ramazani 1966: 256). The ideological affinity between Kemal Atatürk and Reza Shah as a catalyst for Turco-Iranian relations tends to be overemphasised. The OttomanSafavid rivalry was firmly in the past, Turkey did not constitute a hindrance to Iranian independence nor were Iran's frontier disputes as intense with Turkey as they were with Afghanistan and Iraq, the matter having been finally and definitively resolved in May 1937 (as an adage to a 1932 document). With this agreement, the Turkish border expanded to include Little Ararat while Iran gained arable land in Kotur near Van (Akdevelioğlu and Kürkçüoğlu 2006: 363). This exchange is significant an example of Turkish territorial expansion for 
security reasons and challenges status quo credentials. In the periodic revolts by Kurdish populations in Eastern Anatolia the porous borders provided safe heavens. The border adjustment cut off an important avenue of escape for the rebels who had hitherto taken refuge in Little Ararat over the border in Iran. The willingness of Iran to hand over a large area of land is indicative of the bilateral good will that existed, though the advantages of fertile agricultural land in return should not be discounted. The quid pro quo in this deal is perhaps the reason why it is not discussed in the bulk of the secondary literature on Turkish interwar foreign policy.

Tehran's goal of economic independence relied on gaining a measure of trade freedom from the USSR by establishing links to European markets through the Tabriz-Rawaduz and Tabriz-Erzurum roads over Iraqi and Turkish territory (Ramazani 1966: 274). Iran also had an Eastern sea route at its disposal through the Persian Gulf. However, Tehran's search for alternative European assistance to counter that of Britain and the USSR may have been the political objective of a land based European trade route. To serve these ends, a Turkish delegation headed by Cemal Hüsnü Toray spent some months in Tehran signing a number of agreements. A convention was signed in March 1937 concerning frontier security, residence and customs tariffs amongst other similar issues. ${ }^{9}$ The following commercial agreement of 22 April amounted to little more than reciprocal 'most favoured nation' treatment after Iran refused to sign a clearing agreement. ${ }^{10}$ Ankara was attempting to offset its own clearing agreements with European states by exploiting Turkey's comparative ease of access to European markets. The various treaties were ratified by Iran on 5 June 1937, they did not amount to a great deal considering Toray had been in Tehran since the previous October, at that stage a consular agreement was still not concluded. ${ }^{11}$ Although thin on tangible results, the continued presence of a Turkish delegation could have made the Iranian government receptive to Turkish suggestions concerning the Shatt-al-Arab dispute with Iraq.

The Shatt question was chief among the differences requiring resolution for the signature of the Saadabad Pact. The dispute was over the jurisdiction of the waterway, created by the merging of the Tigris and Euphrates rivers, at the point where it pours into the Persian Gulf. The diplomatic traffic in the lead up to the issue's conclusion is littered with, British Ambassador to Turkey, Percy Loraine's discussions with Aras. The majority of them contain reports by Aras on his actions or notifications of future engagements. That the Turkish side would keep Britain informed of its actions is indicative of a Turkish desire for closer relations with Britain and of an awareness of British sensibilities regarding Iraq. Aras' indications that his visits to Baghdad, Tehran and Moscow were merely of courtesy, ${ }^{12}$ seem to betray an attempt at maintaining diplomatic decorum. Seen in the light of reciprocal utterances of a pleasing rapprochement by Prime Minister İsmet İnönü and Loraine, ${ }^{13}$ the facts that a Royal Air Force craft was put at Aras' disposal for his diplomatic missions ${ }^{14}$ and Atatürk's emphasis on the excellence of Anglo-Turkish relations, ${ }^{15}$ may indicate a convergence of interests in seeing a settlement made between Iran and Iraq.

It is not surprising that London scrutinised the draft treaty before discussions on the fourpower pact began. ${ }^{16}$ More significantly the Iraqi Foreign Minister Naji al-Asil showed the draft treaty to the Turkish government. The favourable reaction it received in Ankara coupled with Aras impressing Turkish views towards a favourable settlement of the Shatt issue on the Iranian 
Ambassador in Ankara, ${ }^{17}$ is suggestive of Turkey's pursuance of a foreign policy closely aligned with Britain's in the Middle East. Turkish influence gained here could potentially translate into favourable clauses in the projected four-power pact. Furthermore, Aras' statement that Turkey had a new interest in free navigation through the Shatt due to the dangers posed in the Mediterranean because of the Spanish Civil War, ${ }^{18}$ may also constitute Turkish interest in an alternative maritime communications route. However, the immediate practical significance of this route for Turkey was considerably smaller than the Mediterranean.

Though no definitive Turkish finger can be found on the resolution of the Shatt question until Turkish, Iraqi and Iranian archives can be scrutinised, the amount of circumstantial evidence is intriguing. Clark Kerr, British Ambassador in Baghdad, reported that Aras was still in Tehran on 26 June waiting to sign a non-aggression pact. ${ }^{19}$ Then the Turkish Ambassador in Iran indicated that all difficulties to do with the Shatt question had been removed since the arrival of Aras, adding that the Iraqi Foreign Minister was expected in the next few days, while the Afghan Foreign Minister had also been invited for immediate signature of the pact. ${ }^{20}$ It is interesting to note that this was communicated before the prerequisite conclusion of the Shatt question, throwing into further doubt Aras' visit of mere courtesy. An additional factor was alAsil's belief that a clause in the Shatt treaty relating to a third state's use of both parties' territorial waters in the event of a naval visit, having its origins with the Turkish Foreign Minister. ${ }^{21}$ The Shatt treaty was signed on 4 July 1937, removing the obstacle to Saadabad and leaving Aras at pains to distance himself from suggestions that he had an important role in its conclusion. $^{22}$

The treaty was a compromise deal which left certain questions, such as a navigation convention, essentially untouched. Much as it was facilitated by Turkish involvement, it was also directed by British interests in controlling Iraqi access by sea to Basra and the maintenance of British representation on the conservancy board which was to control the stilting of the Shatt (Watt 1988: 339). Much of the secondary literature suggests that the Saadabad Pact was a diplomatic initiative to show a united front against Italian expansionism (Barlas 1998: 182; Vere-Hodge 1950: 103; Watt 1988: 340). This is normally based on its origins at Geneva in 1935, when international tension was focused on Italy. Although this may have provided the impetus, it is difficult to see how Italy aimed to break the Anglo-French dominance of the Middle East.

Another explanation of Saadabad might be to do with the signatories' relationships with Britain, the USSR and their own border issues. The text of the Pact included provisions for consultation in international disputes, provided for neutrality of the parties in the event of one of them being at war and spelled out what constituted war (Hurewitz 1956: 214-6). The document was far from establishing a Middle Eastern pact, more accurately it was a nonaggression treaty calling for preservation of peace through consultations, importantly it lacked a specific external target (Barlas 1998: 82). The only article with any substance was Article VII:

... The high contracting parties undertake to protect, within his respective frontiers, the formation or activities of armed bands, associations or organisations to subvert the established institutions, or disturb the order or 
security of any part, whether situated on the frontier or elsewhere of the territory of another party, or to change the constitutional system of such other party (Hurewitz 1956: 215).

This was directed against the problems Turkey, Iran and Iraq faced on their respective borders with Kurdish populations. Their resistance to central administrative control had long troubled the three westernmost signatories. Foreign Office records show evidence of mutual IraqiIranian mistrust and reciprocal accusations of harbouring bandits, insurgents and political refugees, communicated at high levels of Foreign Ministry correspondence translated and reported to British representatives. ${ }^{23}$ Turkey, then as now, had problems with its Kurdish population, beginning with the Sheikh Said Revolt in 1925 which continued on smaller scales until 1938 (Uzgel and Kürkçüoğlu 2006: 266). Establishing central control over peripheral populations was a persistent problem. In Iran's case, according to the French and Turkish military attachés, ${ }^{24}$ trouble in the Northwest of the country in June 1937 was caused by the extension of conscription to the Kurdish population. It is therefore understandable that the signatories sought to diminish the effect of the volatile Kurdish issue on their bilateral relations (Akdevelioğlu and Kürkçüoğlu 2006: 366).

With regards to Europe, the Pact was not a reaction to Italy but a part in the rapprochement with Britain for Mediterranean security (Barlas 1998: 181). The corollary effect was to increase the British interest in securing Turkey against Italy. To have British acquiesce in a regional agreement which disturbed the Soviets served, at least in the short term, to decrease Moscow's influence in Ankara. Nevertheless, it was symptomatic of Turkish sensibilities towards Soviet suspicions, which made Aras conclude his diplomatic mission by paying a visit to Moscow, to soothe Soviet suspicions of a British inspired Middle East pact directed against the USSR. Turco-Soviet friendship was affirmed in a communiqué after the talks (Degras 1953: 247), but the curtness of the statement must have had a negative effect on Aras. Much was also made of Stalin's refusal to grant a meeting to the Turkish delegation after indicating that one would take place. $^{25}$ The previous heavy reliance on Soviet approval was being replaced by increasing British favour.

Of the Pact's signatories, perhaps only Turkey saw it in the light of strategic concepts. It represented a non-Arab option for Iraq (Watt 1988: 334). Afghanistan was not enthusiastic about the alliance but recognised it as an opportunity for some respite from border tensions with Iran (Adamec 1974: 233). In Iran, Reza Shah was seeking to further relations with Turkey and Iraq to diversify market access. Though this remains rather simplistic in discussing motivations of the powers other than Turkey, the other signatories had no existing security arrangement such as the Balkan Entente to link up a system of security guarantees. Eventually, it was war in Europe and Turkish focus on Balkan and Mediterranean defence which negated Saadabad in real terms. British, French and Soviet control over the Middle Eastern status quo was stronger than their ability to influence European developments. The novelty of the Pact's initiative by newly independent Middle Eastern states had the effect of antagonising the USSR. Its aim was to freeze the regional status quo allowing the signatories space for other external policy (Watt 1988: 335) and internal development. 
Ankara played an important role in mediating a dispute between Iran and Iraq, with the longer-term objective of placing Turkey in a defensive system. This system aimed to protect Turkey from potential threats emanating from its eastern borders and an important portion of its population resistant to centralisation. The resulting warmth of relations with Britain and cooling with the USSR has been used to place Turkey in the status quo camp. This has been challenged since the USSR, in so far as historians discuss Turkish interwar foreign policy, is placed in neither. The legality of the Saadabad Pact, the nature of the amicable signature, and expressions of good faith coupled with articles which did not revise Turkey's borders at the expense of other signatories also indicated that Turkish overtures towards its sovereign Middle Eastern neighbours had similar qualities to its efforts towards Europe and contributed to the Middle Eastern status quo. Nevertheless, this also afforded scope for Turkey to pursue revisionism elsewhere in the Middle East.

\section{The Sanjak Dispute of Alexandretta, 1936-39}

The dispute over what is today the Turkish province of Hatay is perhaps the most powerful argument for classifying Turkey as a revisionist power. It stems from the fact that Turkey enlarged its territory significantly with this acquisition at the expense of Syria which was hamstrung by French interests. Further, it was not only stubborn irredentism on the Turkish part, but also abrogation of the post-Paris mandate system, achieved by directly challenging the League of Nations. It can be reasonably asserted that Turkey took advantage of appeasement in Europe to bring about a successful contemporary revisionist policy. Turkish action in this instance was similar to German revisionism in Central Europe. However, suggesting overall Turkish revisionism would be to assert a closer alignment with Germany and Italy following conclusion of the dispute. In contrast, the net result was to bind Turkey closer to Britain and France, undermining both the revisionist and status quo positions.

The Sanjak ${ }^{26}$ of Alexandretta has an important place in Franco-Turkish relations from 1936 onwards. The determinants of this issue were instability in Europe, the increase in Turkish freedom of foreign policy action and some British mediation. Syria, as a result of the mandate had little sway over the matter. That the eventual settlement of this issue expanded Turkish territory had implications for Turkey's asserted standing as a status quo power. If Ankara brought about an expansion of Turkish territory during the interwar period by repudiating the 1919 Paris agreements, asserting a claim on non-sovereign territory on the basis of ethnolinguistic affinity and military posturing would that not put it in the same revisionist camp as Germany and Italy?

Alexandretta (İskenderun) and Antioch (Antakya) were included in the Turkish National Pact, ${ }^{27}$ yet became part of the new Syria established under the French mandate. By the mid1930s, Germany's reoccupation of the Rhineland added to by the failure to find oil reserves in Syria shifted French priorities. Keeping direct hold over the mandate was less feasible in view of the resources spent. Indigenous Syrian resistance to French mandatory control was also important in French calculations (Shields 2011: 27). The 9 September 1936 Franco-Syrian Treaty towards the abolition of the mandatory regime would see the Sanjak come under exclusive Syrian control after independence (Uzgel 2006: 283). Turkey, which had previously 
negotiated with France for the special status of the Sanjak's Turkish population, became alarmed at the substitution of a French mandate over Alexandretta for a Syrian one, and resolved to follow a policy which would gain home rule for the Sanjak. ${ }^{28}$ The implication contained was one of dismemberment, the French and Syrians objected (Vere-Hodge 1950: 116). The diplomatic tension was reflected in the developments on the ground. A pro-Turkish disturbance in Antioch left three dead but not have wide ranging impact. Consequently, some Turkish newspapers, which sensationalised anti-Turkish atrocities, were closed down. ${ }^{29}$

In December 1936, Turkey and France accepted the referral of the matter to the League of Nations. ${ }^{30}$ The League team of observers submitted their Sandler Report on 17 January 1937. It recommended the establishment of a distinct entity in the Sanjak, a joint Turkish-French guarantee of its territory, a monetary and customs union with Syria, the equality of Turkish and Arabic as official languages and a special arrangement for Turkey to use the Alexandretta harbour (Uzgel 2006: 284). A further League committee prepared the constitution of the Sanjak. The results were accepted by the Council of the League of Nations on 29 May 1937, thus legally establishing the 'separate entity' (Mango 1999: 507). According to this resolution, elections to the Sanjak's assembly were to take place on 15 April 1938. A League election committee began work in the summer of 1937 to arrange this. However, the submission of their plan without consulting Turkey drew a dramatic response from Ankara. The Turkish government cancelled the Turkish-French Treaty of Friendship of 1930 in December 1937 (Uzgel 2006: 228). It would seem that Paris did not heed Atatürk's warning of the preceding month that Turco-French relations were dependent on the outcome of the Sanjak question. ${ }^{31}$ As long as France maintained the status quo in Syria, Franco-Turkish relations were maintained on a friendly if limited basis (Shmuelevitz 1988: 313). Now that the status quo was in the process of being modified and supported by a League resolution, Ankara found opportunity to play an active role in the settlement of the issue on its terms.

By 29 June 1938 Ankara was still displeased with the electoral commission's work. France was unwilling to quarrel with Turkey over an area it would lose with the end of the mandate. Seeing that Turkish control of the Straits would be an important link in Franco-Soviet communications in the event of war, Paris sacrificed the interests of Syria and the non-Turkish inhabitants of the Sanjak to strengthen the French defensive system (Trask 1971: 235). As a direct consequence, the League of Nations electoral commission left the Sanjak, relinquishing control of the electoral administration to Turkey and France, thus placing it outside the mechanisms of international scrutiny (Uzgel 2006: 288). Now that Turkey had wrested control of the election from the League, a new Franco-Turkish treaty replaced the one cancelled in December 1937. The new Treaty of 4 July 1938 allowed for a joint French-Turkish security detachment to be placed in the Sanjak of no more than 2,500 men each (Uzgel 2006: 288). That Ankara gained the right to station troops outside its sovereign territory has provided much ammunition for those maintaining that Turkey was and is a revisionist state.

According to the French census, the total population of the Sanjak was 219,080. The ethno-religious breakdown was as follows; 85,242 Sunni Muslim Turks, 62,026 Alawites, 24,911 Armenians, and 22,461 Sunni Muslim Arabs, the remainder being made up of Christians (other than Armenian), Jews, Circassians and others. ${ }^{32}$ The Turkish government put the ethnic Turkish number much higher, claiming a distinct majority rather than the largest 
single group in a diverse population. This was due to the Alawite element which constituted $28 \%$ of the total. The population list, drawn up on ethno-religious lines, neglected the linguistic predicament of this group. Individual Alawites could register themselves as an Arab or Turk depending on their mother tongue (Uzgel 2006: 287).

The French-Turkish electoral commission allocated 22 of the 40 seats of the Sanjak assembly to Turkish delegates. ${ }^{33}$ The pro-Turkish element had gained a parliamentary majority without a single vote cast. The propriety of this convenient number has been called into question, indicating a diplomatic gentleman's agreement between Ankara and Paris holding strategic security interests above fairly conducted elections (Shields 2011: 193). The 24 August elections did little more than rubber stamp the engineered outcome. When the assembly convened for its first session on 2 September all deputies swore an oath in Turkish. Three Turks took the top three jobs of the state, Abdülgani Türkmen became the Speaker of the Assembly, Tayfur Sökmen headed the state and Abdurrahman Melek became Prime Minister, the name of the separate entity was changed to Hatay (Uzgel 2006: 289).

The negotiations surrounding the Tripartite Alliance between Britain, France and Turkey in 1939 brought about the final inclusion of Hatay into Turkey. When Germany invaded the rest of Czechoslovakia in March 1939 and cancelled its non-aggression pact with Poland, the British desire to have Turkey on side coupled with the French General Staff's estimation of Turkish use in Mediterranean security persuaded the French government to cede the Sanjak to Turkey (Uzgel 2006: 290). The cessation was agreed between the Turkish Foreign Minister Şükrü Saraçoğlu and the French Ambassador to Turkey René Massigli on 23 June 1939 (VereHodge 1950: 118). The formalities were finalised and Hatay was the newest province of the Turkish Republic by July 1939 (Shields 2011: 239). In essence Turkey's most revisionist action in the interwar period produced its closest alliance, to the status quo bloc.

As for Turkish revisionism, the scattered evidence in British records shows that Turkey pursued an active policy aiming at the eventual inclusion of the Sanjak into Turkey. The French delegate in Alexandretta explained to the British Consul in Aleppo that the Turks had sent several agents to stir up the pro-Turkish element in the Sanjak and that the Turkish government had stationed two divisions of troops on the border. ${ }^{34}$ The Syrian government was seething at the prospect of partition, accusing Turkey of diplomatic manoeuvring under a halo of selfrighteousness and political rectitude to eventually occupy the Sanjak. ${ }^{35}$ In Turkey, nationalist euphoria of the time contributed to public backing of Turkish foreign policy, though this was likely directed by Ankara. Hatay Independence Committees were set up for the propagation of the Turkish case by Turks originating from the Sanjak. ${ }^{36}$ This organisational initiative of the Turkish side was an important factor in bringing about a pro-Turkish resolution.

The source of British information on the Sanjak was the Aleppo Consulate. It described the majority of the population as inarticulate and therefore politically negligible. The leaders at their heads, Arab or Turk, were equally extreme in their demands originating in either Damascus or Ankara. ${ }^{37}$ Crucially, Turkey had the resources and skills that took much from the administrative structure of the Ottoman Empire. There was continuity and experience in diplomatic and subversive intercourse. Syria as a younger state could not match the combined powers of French interests and the organised nationalism of Ankara (Shields 2011: 10). The Turks dealt with a compact, disciplined and better educated body of supporters through a direct 
channel of specifically appointed consular representatives in Antioch and Alexandretta. Further, Sanjak immigrants in Turkey were being encouraged to return at the expense of the Turkish Treasury. ${ }^{38}$

Much of the literature asserts that Turkey was a status quo nation in an international environment favourable to territorial expansion. Indeed, the expansion of Turkish borders was achieved under the rubric of the League of Nations, in accordance with international law and generally by the book (Uzgel 2006: 291). However, this interpretation ignores Turkish propaganda activity in the Sanjak, the implied threat of military intervention through massing troops at the border and the growing impotence of the League of Nations from the mid-1930s onwards. A saving grace is perhaps that Mosul was also included in the National Pact and that after its settlement in 1926, the issue was dropped. Here however there is another problem of circumstance. The League at that stage was the legal instrument of the winners of WWI and preceded the emergence of the revisionist bloc.

Weber's assertions to the contrary go too far in an assumed revisionist - status quo divide. His claim that Aras threatened to side with Germany and Italy after being contradicted on the population of the Sanjak at the League of Nations (1979: 11), does not account for the Turkish strategy of garnering the maximum advantage from the contemporary European Great Power relations. He takes Aras' statement at face value. Similarly, that Turkey massed military units on the Bulgarian frontier in autumn 1938 is viewed as sabre rattling for territorial expansion in the Balkans (Weber 1979: 21). The fact that the border under question had recently been allowed remilitarisation with a Bulgaria-Balkan Entente treaty is ignored, as is the German occupation of the Sudetenland with its long-term implications on the security of the Balkan Entente.

Neither conclusion seems satisfactory. The area of expansion, the strategic context and the internal situation made it a favourable and pragmatic foreign policy goal for Ankara. The mandate system allowed the subordination of local interests to nation-state ones. It can be argued that Turkish revisionism here was a response to the altered status quo emanating from the Franco- Syrian Treaty of 1936. Once it was politically expedient for France to cede the territory as a quid pro quo for a Turkish alliance in furtherance of the Anglo-French defensive system in Europe and the Mediterranean the matter was concluded. It had only to go through the motions of League of Nations red tape. When this proved unsatisfactory the established practice of marginalising the League was continued. That Syria was not an independent state was also important. No such action could have taken place elsewhere on Turkey's borders. The failure of appeasement in Europe allowed Turkey to take advantage of the instability. By sticking nominally to the book of international law and gaining Great Power acquiescence before any tangible move, Turkish expansion gained an important attribute of pragmatism and legitimacy that German and Italian revisionism lacked. It was essentially a politically expedient deviation from an overall policy more closely aligned with contemporary status quo powers. Nevertheless, it was an act of revisionism, putting further strain on a simple dichotomous interpretation of Turkish interwar history.

It has been shown that Turkey substantially added to its borders with the acquisition of Alexandretta and Antioch prior to WWII. This was achieved by deploying state resources in favour of the Sanjak's Turkish population, marginalising the League of Nations and projecting 
military force. In short Turkey demonstrated revisionism, undermining the claim of status quo historiography. However, focusing exclusively on the Sanjak issue without regard to Turkish actions to maintain the status quo elsewhere also does damage to the revisionist claim. Calculated self-interest can lead to policies of both revision and status quo, which should be regarded neither as inherently malicious nor benevolent.

\section{Concluding Remarks}

Each of the themes discussed have been an attempt to place the aims of Turkish policy in their international and historical context. Turkish considerations were directed towards maintaining and solidifying its existence as a nation state. This was to be achieved by categorising the intentions, strengths, weaknesses and usefulness of Turkey's neighbours and the European Powers. Turkey responded and initiated policy towards the attributes of each as they became apparent. These constituted the data by which Ankara conducted its foreign affairs by weighing them against the available international machinery and the prevailing political conditions.

Turkey's position as a status quo or revisionist state seems difficult to establish. In the period under analysis, Ankara remilitarised the Straits and Thracian borders, added Alexandretta and Little Ararat to Turkish borders while relinquishing Kotur. Viewed arithmetically in this manner, Turkey must be placed in the revisionist bloc. The manner of expansion however, differed significantly from that of Germany and Italy. The Little AraratKotur exchange was a reciprocal agreement that benefited both parties; importantly this bilateral exchange did not infringe on Lausanne. In Thrace and the Straits, Turkey did not take unilateral action. If revisionism in this period is characterised by some combination of ethnolinguistic irredentism, military action, unilateral repudiation of standing agreements through faits accompli and these occasionally being buttressed by new treaties, then garnering international diplomatic support and gaining a compromise with those involved to bring about a change to international agreements cannot be considered the actions of an aggressively revisionist state. Rather it can be considered a controlled, careful and agreed modification of the status quo. Change in and of itself does not constitute revisionism. Indeed, it is not clear in the literature how many status quo or revisionist foreign policy outcomes or intentions are required to assign a label. Further, if change is taken as a larger concept which social scientists study, how far can it be used without being pigeonholed into foreign policy revisionism in the interwar period?

It is because of Turkey's increasing international diplomatic credibility after Montreux and Saadabad that the Sanjak issue is problematic for those espousing a status quo position. Syria was ignored, and an agreement concluded with France with initial input from the League of Nations. When Turkey was unhappy with the work of the League, Ankara demonstrated intransigence, calculating that Turkey was more important to France and Britain than Syria. Massing troops on the border, organising pro-Turkish propaganda and biased interpretation of population data are contemporary revisionist practices. At worst, it was a parallel to German action in the Sudetenland. At best, it may be seen as a prejudicial marginalisation of Syria in favour of Turkey within the prevailing boundaries of diplomacy and security politics. 
A conclusion must incorporate Turkish revisionism tied to the necessary advantages and limitations of diplomacy. Since in any given circumstance a state will seek the maximum benefit, it may be expected that Turkey took the actions it did. Ankara was able to deploy revisionist tactics against mandated Syria. Where sabre rattling would clearly not work or was not necessary, Turkey engaged in diplomacy. Finally, it might not be Turkey's place on a polarised historiography which should be questioned, but that it is placed within it in the first place. Dichotomisation of a non-Great Power according to Great Power circumstances is of questionable use in fluid circumstances. On this basis Turkey was neither a revisionist nor a status quo state in the interwar period.

\section{Notes}

1. FO 424/281, E 812/141/44, Loraine to Eden 6 February 1937.

2. Romania and Yugoslavia were not signatories to Lausanne, their inclusion is an indication of the importance Turkey placed on them as Balkan Entente allies.

3. See also for the text of the Montreux Convention, pp. 198-203.

4. FO 424/281, E1592/1592/44, Eden to Loraine, 6 April 1937.

5. FO 424/281, E 1262/83/44, Loraine to Eden, 25 February 1937.

6. FO 424/281, E 156/528/44, Loraine to Eden, 12 March 1937.

7. FO 371/20860, E 3238/188/44, Morgan to Foreign Office, 14 June 1937.

8. FO 424/281, E 4769/83/44, Scott to Eden, 5 August 1937.

9. FO 416/95, E 2277/1117/34, Seymour to Eden, 9 April 1937.

10. FO 416/95, E 2566/1117/34, Seymour to Eden, 23 April 1937.

11. FO 416/95, E 3687/1117/34, Seymour to Eden, 19 June 1937.

12. FO 371/20860, E 2042/188/44, Loraine to Eden, 9 April 1937.

13. FO 371/20852, E 2059/16/44, Loraine to Eden, 19 April 1937.

14. FO 371/20860, E 4402/188/44, Loraine to Foreign Office, 26 July 1937.

15. FO 424/281, E 6647/466/44, Loraine to Eden, 1 November 1937.

16. CAB 21/576, Naji al-Asil to Kerr, 4 March 1937, enclosure in E 1378/73/34, Kerr to Eden, 5 March 1937.

17. FO 248/1399, 49/45/37, Loraine to H.M. Minister in Tehran, 1 May 1937.

18. FO 416/95, E 4479/188/44, Seymour to Eden, 14 July 1937.

19. FO 248/1399, 49/61/37, Kerr to Foreign Office, 26 June 1937.

20. FO 248/1399, 49/58/37, Seymour to Foreign Office, 29 June 1937.

21. FO 248/1399, 49/63/37, H.M. Minister in Tehran to Foreign Office, 2 July 1937.

22. FO 371/20860, E 4479/188/44, Seymour to Eden, 14 July 1937.

23. FO 248/1400, 217/6/37, British Ambassador Baghdad to H.M. Minister in Tehran, 10 June 1937, \& 217/6/37, Kerr to Foreign Office, 31 May 1937.

24. FO 248/1400, 217/5/37, Seymour to Tabriz, 12 June 1937.

25. CAB 21/1020, E 6634/386/44, Loraine to Eden, 2 November 1937.

26. Ottoman administrative sub-province. 
27. The territorial and political manifesto of the Turkish nationalist leadership during the War of Independence, 1919-22.

28. British Documents on Foreign Affairs (BDFA), Morgan to Eden, 12 September 1936.

29. BDFA, Acting Consul Davis (Aleppo) to Eden, 12 December 1936.

30. BDFA, Loraine to Eden, 2 December 1936.

31. FO 424/281 E 6662/188/44, Loraine to Eden, 5 November 1937.

32. BDFA, Report on French-Turkish Dispute over the Sanjak of Alexandretta.

33. BDFA, Consul Davis (Aleppo) to Halifax, 6 August 1938.

34. BDFA, Acting Consul Cantoni (Aleppo) to Eden, 24 November 1936.

35. BDFA, Consul MacKereth [Damascus] to Eden, 13 December 1936.

36. BDFA, Loraine to Eden, 5 January 1937.

37. BDFA, Consul Davis (Aleppo) to Eden, 23 December 1937.

38. BDFA, Consul Davis (Aleppo) to Eden, 23 December 1937.

\section{References}

*Public Records Office (The National Archives), London, UK: CAB 21/576, CAB 21/2010, FO 248/1399, FO 248/1400, FO 371/20852, FO 371/20860, FO 416/95, FO 424/281.

Adamec, Ludwig (1974) Afghanistan's Foreign Affairs to the Mid-Twentieth Century: Relations with the USSR, Germany and Britain (Tucson: The University of Arizona Press).

Akdevelioğlu, Atay, and Kürkçüoğlu, Ömer (2006) 'Orta Doğu'yla İlişkiler', in Baskın Oran (ed.) Türk Dış Politikası: Kurtuluş Savaşından Bugüne Olgular, Belgeler, Yorumlar. Cilt 1: 1919-1980 (İstanbul: İletişim), pp.357-369.

Barlas, Dilek (1998) Etatism and Diplomacy in Turkey: Economic and Foreign Policy Strategies in an Uncertain World, 1929-1939 (Leiden: Brill).

_ (2005) 'Turkish Diplomacy in the Balkans and the Mediterranean. Opportunities and Limits for Middle-Power Activism in the 1930s', Journal of Contemporary History 40 (3), pp.441-464.

Bilge, Suat (1992) Güç Komşuluk: Türkiye Sovyetler Birliği İlişkileri, 1920-1964 (Ankara: Türkiye İş Bankası Kültür Yayınları).

Birdwell, Robin (ed.) (1986) British Documents on Foreign Affairs. Vol. 12. Reports and Papers from the Foreign Office Confidential Print, Eastern Affairs, June 1936-June 1938 (Bethesda: University Publications of America).

Degras, Jane (ed.) (1953) Soviet Documents on Foreign Policy, 1933-1941. Vol. 3. (London: Oxford University Press).

Deringil, Selim (1989) Turkish Foreign Policy During the Second World War: An 'Active' Neutrality (Cambridge: Cambridge University Press). 

Cassell).

Eden, Anthony (1962) The Eden Memoirs: Facing the Dictators, Vol. 1 (London:

Güçlü, Yücel (2000) ‘Turkish-German Relations on the Eve of World War Two' Turkish Studies 1 (2), pp. 73-94.

Hale, William (2000) Turkish Foreign Policy 1774-2000 (London: Frank Cass).

Hurewitz, Jacob (1956) Diplomacy in the Near and Middle East: A Documentary Record: 1914-1956. Vol. 2 (Princeton: D. Van Nostrand Company).

Mango, Andrew (1999) Atatürk (London: John Murray).

Millman, Brock (1995) 'Turkish Foreign and Strategic Policy 1934-42' Middle Eastern Studies 31 (3), pp. 483-508.

Oran, Baskın (2006) '1923-1939 Göreli Özerklik - 1' in Baskın Oran (ed.) Türk Dış Politikası: Kurtuluş Savaşından Bugüne Olgular, Belgeler, Yorumlar. Cilt 1: 1919-1980 (İstanbul: İletişim), pp. 241-257

- (2006) 'TDP'nin Kuramsal Çerçevesi' in Baskın Oran (ed.) Türk Dış Politikası: Kurtuluş Savaşından Bugüne Olgular, Belgeler, Yorumlar. Cilt 1: 1919-1980 (İstanbul: İletişim), pp. 20-53.

Özersay, Kudret (2006) 'Montreux Boğazlar Sözleşmesi' in Baskın Oran (ed.) Türk Dış Politikası: Kurtuluş Savaşından Bugüne Olgular, Belgeler, Yorumlar. Cilt 1: 1919-1980 (İstanbul: İletişim), pp. 370-84.

Ramazani, Rouhollah (1966) The Foreign Policy of Iran: A Developing Nation in World Affairs, 1500-1941 (Charlottesville: University Press of Virginia).

Sharp, Alan (1991) The Versailles Settlement: Peacemaking in Paris, 1919 (London: Macmillan).

Shields, Sarah, D. (2011) Fezzes in the River: Identity Politics and European Diplomacy in the Middle East on the Eve of World War II (Oxford: Oxford University Press).

Shmuelevitz, Aryeh (1988) 'Atatürk's Policy Towards the Great Powers: Principles and Guidelines', in Uriel Dann (ed.) The Great Powers in the Middle East 1919-1939, (New York: Holmes \& Meier), pp. 311-316.

Shotwell, James, and Francis Deák (1940) Turkey at the Straits: A Short History (New York: Macmillan).

Soysal, İsmail (1981) 'Türkiye'nin Batı İttifakına Yönelişi, 1934-1937', Belleten 45 (177), pp. 95-155.

Trask, Roger (1971) The United States Response to Turkish Nationalism and Reform 1914-1939 (Minneapolis: The University of Minnesota Press). 
Uzgel, İlhan (2006) 'Almanya'yla İlişkiler' in Baskın Oran (ed.) Türk Dış Politikası: Kurtuluş Savaşından Bugüne Olgular, Belgeler, Yorumlar. Cilt 1: 1919-1980 (İstanbul: İletişim), pp. 297-306.

_ (2006) 'Fransa'yla İlişkiler' in Baskın Oran (ed.) Türk Dış Politikası: Kurtuluş Savaşından Bugüne Olgular, Belgeler, Yorumlar. Cilt 1: 1919-1980 (İstanbul: İletişim), pp.277-291.

Uzgel, İlhan, and Kürkçüoğlu, Ömer (2006) 'İngiltere’yle İlişkiler’ in Baskın Oran (ed.) Türk Dış Politikası: Kurtuluş Savaşından Bugüne Olgular, Belgeler, Yorumlar. Cilt 1: 19191980 (İstanbul: İletişim), pp. 258-77.

Vere-Hodge, Edward (1950) 'Turkish Foreign Policy 1918-1948', Unpublished Thesis, Université de Genève, Switzerland.

Watt, Cameron (1988) 'The Saadabad Pact of 8 July 1937' in Uriel Dann (ed.) The Great Powers in the Middle East 1919-1939 (New York: Holmes \& Meier), pp. 333-52.

Weber, Frank (1979) The Evasive Neutral: Germany, Britain and the Quest for a Turkish Alliance in the Second World War (Columbia: University of Missouri Press).

Zhivkova, Ludmila (1976) Anglo-Turkish Relations 1933-1939 (London: Secker \& Warburg).

\section{Acknowledgements}

The author would like to thank Dr Steve Morewood, Dr Alexander Martin and the anonymous reviewers for their helpful comments on this article.

\footnotetext{
About the Author

Mustafa Çoban is a PhD Candidate in the School of History and Cultures, Centre for Byzantine, Ottoman and Modern Greek Studies at the University of Birmingham, UK. His research is focused on Turkey's treaties with Balkan and Middle Eastern neighbour states in the interwar period.
} 